\title{
Overview of flooding damages and its destructions: a case study of Zonguldak-Bartin basin in Turkey
}

\author{
Hasan Arman ${ }^{1,3}$, Ibrahim Yuksel ${ }^{2^{*}}$, Lutfi Saltabas ${ }^{3}$, Fatih Goktepe ${ }^{3}$, Mehmet Sandalci ${ }^{3}$ \\ ${ }^{1}$ College of Science, Department of Geology, United Arab Emirates University, Al-Ain, UAE; Harman@uaeu.ac.ae; \\ harman@sakarya.edu.tr \\ ${ }^{2}$ Faculty of Technology, Department of Construction, Sakarya University, Esentepe Campus, Sakarya, Turkey; \\ yukseli2000@yahoo.com; iyuksel@sakarya.edu.tr \\ ${ }^{3}$ Engineering Faculty Department of Civil Engineering, Sakarya University, Esentepe Campus, Sakarya, Turkey
}

Received 29 December 2009; revised 26 January 2010; accepted 2 February 2010.

\begin{abstract}
A number of devastating flood events have occurred in the various river basins of Turkey in the last decade. Because floods caused deaths, suffering and extensive damages to both public and private properties in the flood areas, the government had to most of the damage in addition to losing significant revenues due to the consequences of costly social and economic disruption. On the other hand, some social structures such as socioeconomic activities, land-use patterns and hydro-morphological processes are destroyed. Whereas flood control structures are considered as one of the basic strategies that can reduce flood damages and in this context flood protection planning should consider the full range of the hazard mitigation activities. In Turkey, between 1945 and 1990, 737 flooding events were occurred and at least 830 people were killed. In 1998, there was a major flooding in Zonguldak-Bartin region located on north of Turkey. Due to this devastated flooding, people lost their life and numbers of engineering structures built on the river and surrounding area were totally destroyed or heavily damaged. Both side of the canal were covered with muddy soil having $0.10-0.15 \mathrm{~m}$ thickness. Cleaning up process took sometimes in the region. In this paper, all these subjects have been investigated in the basin and some engineering proposals have been presented.
\end{abstract}

Keywords: Flood Damages; River Management; Zonguldak-Bartin Basin; Flood Control

\section{INTRODUCTION}

Beside social, economical, technological, administrative and political gains during the development from primarily communities to our information communities throughout the history some hard to solve problems for the future generations and for us about our environment had occurred, especially because of industrialization and urbanization attempts that do not care about environment in spite of their economical profits. Due to global economic order that overbalance the ecosystem, environment problems, which did not exist in twenty century, exist in last twenty-five year. Problems like population increase, decrease in agriculture land area, reduction of ground water, devastation of forests, disappearing of plants and animal kinds, air-water-soil pollution, increase of temperature because of greenhouse gases, are vital for humanity. As a result of this, because of climatic changes it is expecting that there is a risk of hurricanes, strong precipitations, or long-term drought, risk of lands turning into desert [1]. Floods are due to heavy rainfall on the coastal areas of the western and southern parts of Turkey or to a sudden increase in air temperature, resulting in snow melt in the eastern, mountainous part of southeastern Turkey especially Eastern Black Sea Region $[2,3]$. In the northern and central parts of the country both factors may occur depending on the time of the year.

In Turkey the precipitation types are frontal, orographic, or convective. During occluded fronts, long lasting, intense rainfall may produce flooding depending on the season of the year. Besides most of the coastal precipitation in the Black Sea region where the range of mountains runs parallel to the shore sea, considering some others properties of the region such as hydraulics, hydrological, meteorological characteristics at least a few floods have occurred in a year in this region $[4,5]$. Convective precipitation mostly occurs during the transition seasons of spring and autumn and affects central Anatolia. The snow accumulated in the upper reaches of the drainage basins of Anatolian rivers melts, starting 
from the beginning of February or March, and can cause flooding in downstream areas of the rivers. When the general evaluate of the natural balance irregularities arising at a global scale is made, it can be seen the affecting parameters, which are subject to change, are the hydraulic and hydrological ones due to their activities in the river basin. In some areas almost all the waters of the rivers are used up with in the basin, primarily for the purpose of irrigation.

Flash floods are a common, but it is not easy to estimate its environmental features. A lack of accurate environmental data creates much of the uncertainty associated with flash flooding events. In addition to limiting the understanding of hydrological processes, human use and development in a region cause number of problems. Extreme events often exert a disproportionately large effect on the environment, for larger than that associated with the more commonplace typical events, and are those most associated with hazards to humans [6]. A major concern with flash flooding is the development within a very short period of time. Human life and infrastructures are under a major threat of flash flooding. The lack of understanding sometimes compounds problems of flooding, with settlement, road and other structures inappropriately located and designed relative to the flood risk [6].

It is a general accepted fact that especially the dams constructed at a point very close to the shoreline destroy the natural balance of shoreline by totally changing the flow regimen and therefore the sediment load in the rivers. This point, according to one point of view constitutes the crossing point of the shorelines management and the basin management; according to another point view it constitute the intersection between the two basic purposes of both approaches is to watch the natural balance and maintain development. Then, the problem could easily be solved in case there is sustainable growth. In order to achieve joint management, it is obvious that a good monitoring study has to be done and healthy data must be obtained [7].

In Turkey, it is known that erosion flooding and land sliding events are widespread due to unconsciously destruction of nature, and weathering. In many regions of our country flooding and land sliding cause death, wealth loses every year. Although they are not the only environment problem, it is important to consider about these, which time-to-time influence the daily life [1].

This paper deal with the effectiveness of river flooding and its destructive damages on human and their structures built on the river and its surrounding area. Flooding in the Zonguldak-Bartin region during the summer of 1998 caused extensive damage. Immediately after the 1998 floods the Turkish Government took steps to rescue and remove both people and property from flooding area and built up a temporary bridge on the river to provide access people living on both side of the river.

\section{FLOOD INVENTORY AND EXITING FLOOD MEASURES IN TURKEY}

The existing flood related measures carried out in the framework of flood management can be summarized as:

- Structural Projects: Structural projects keep flood waters away from an area with a levee or reservoir, or other measure that controls the flow of water.

- Hydrometric and Meteorological Observation Works: In an attempt to determine reverie flood hazard by catchments area characteristics, such as rainfall and stream flows.

- Survey Reports on Past Floods: State Hydraulic Works (DSI) has been preparing survey reports soon after flood events to establish actual flood damage information and area of inundation. These reports also include date, time, duration, place, meteorology, hydrology and hydraulic of each flood event. The study method is based on field interviews, questionnaires, observations and flood records. The survey reports of each year are formed as flood yearly book by DSI.

- Surveys Relating to Land Use Plans: As all settlement and construction areas are subjected to land use planning permission, DSI carries out flood surveys, which are conveyed to municipalities or governmental organizations and institutions for use as data at the planning stage.

- Regional Flood Plans: DSI prepares regional flood plans that have the basin-wide coverage to be integrated to basin disaster plan for using in the emergency management of the future disasters in the ba$\sin$.

- Stream bed modification by setting up new diversion structures, dykes and groins.

- Reforestation, land improvement.

- Education and information.

However, the methods listed above are available and applied at many places, that does not mean that they are effective everywhere. And the last item education is relatively short-lived. If no practical proof of the theoretical information is given, the knowledge and awareness of the risk will be lost within a few years, even if it was there at the beginning [8]. As long as human continue to built any kind of engineering structures such as dams, highways, bridges, homes and etc. on flood-prone area it can expect continued loss of lives and property. Factors that control the damage cause by floods include:

- Land use on the floodplain, 
- Magnitude (depth and velocity of the water and frequency of flooding),

- Rate of rise and duration of flooding,

- Season (for example: crops on floodplain),

- Sediment load deposited,

- Effectiveness of forecasting, warning emergency systems [9].

Primary effects include injury and loss of life, along with damage caused by swift currents, debris and sediment to farms, homes, buildings, railroads, bridges, roads and communication systems. Erosion and deposition of sediment in the rural and urban landscape can also involve a loss of considerable soil and vegetation. Secondary effects can include short-term pollution of rivers, hunger and disease and displacement of people who have lost their home. In addition, fire may be caused by short circuits or broke gas mains [9]. Relationships between land use and flooding of small drainage basin may be quite complex. Use of agricultural land may affect the flooding. Urbanization is not the only type of development that can increase flooding [9]. Land cover has a strong influence on key hydrological variables such as infiltration and evaporation [6].

\section{FLOOD AND WATER MANAGEMENT}

\subsection{The Use of Floodplain and Floodwaters along the Rivers}

In the some basin at urban area, flood plains along the rivers crossing cities and towns are used for car parking, recreational purpose and for sporting activities, but at rural areas, the flood plains are used for agricultural or others purpose. The farmers cultivate at their own plots as before the land acquisition, but if the flood occurs, with the help of local legal people, sue the state for repayment. The flood waters are not used under any circumstances; the local people and authorities try to get rid of the water as quickly as possible [8].

\subsection{Flood Warning System}

Experiences gained from the floods of last decade show that structural measures implemented in the basin-wide are effective but too costly in reducing the risk of flood damages. In this respect, it has been considered that more importance should be given to non-structural measures, particularly modification of traditional land use and updating building code guidelines and design standards, early flood warning system, creation of public awareness, insurance and timely and effective emergency management, in order to be more effective for integrated flood management in the project area and in the whole country. Due to economic limitations, nonstructural measures imposed by the local municipalities are not always successful. Because the local municipality authorities had to receive the money from central government for the realization of the infrastructures, for example their budget can not cover the land use modification projects. Briefly, the existing non-structural measures are not always successful because of two main reasons [8]:

- In the present situation, the non-structural measures are mostly dealt with by the local administrations including municipalities and mayors. However, due to the present economic conditions, the implementations of the needed activities by these bodies are limited.

- The local units do not have enough educated and trained personnel to implement the nonstructural measures.

On the other hand, in Turkey, local non-Government Organizations (NGOs) are themselves at developing stage. The other point is that the development stage of local non-governmental organizations (NGOs) is not yet satisfactory in dealing with flood disasters.

\subsection{Modification in Flood Mitigation}

Within the framework of flood management, with the increase of structural measures, it is true that the occurrences of floods and their damages become less in Turkey. However, in the recent years, the more importance is given to the non-structural measures, in a given comprehensive plan, including the arrangement of the human activities, the education of the people and the informing of the stakeholders.

From the last experiences, it is understood that the most of the damages is directly related to the fact that the irregular and uncontrolled urbanization at the high-risk areas in the flood plains. In this regard, this approach gives the more responsibility to the local governments and municipalities. There are also some mitigation activities done during the flooding events. These are mostly related to rescue works and emergency studies.

\section{FLOOD AND WATER MANAGEMENT INSTRUMENTS}

\subsection{Existing Laws Related to Integrated Flood Mitigation Concept}

The basic legislation in water sector is the Turkish Constitution, which states that water resources are natural wealth of the country, and under the authority of the State, to be used for the benefit of public. In this direction, the Turkish Civil Code covers water both common waters and private waters. The Red Crescent does the first aid, and the General Directorate of Disaster Affairs 


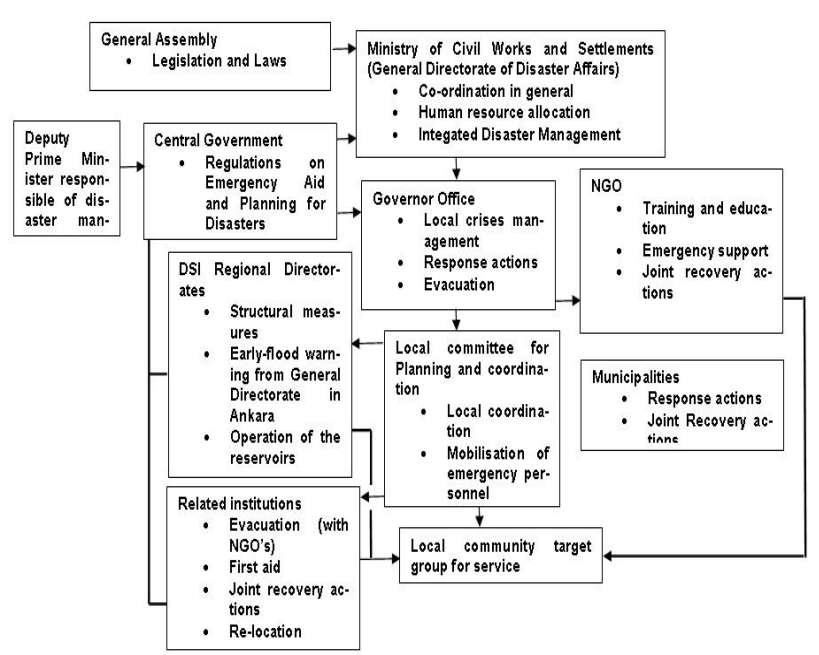

Figure 1. The flow chart in Turkish disaster management system.

(AFET) does the flood mitigation work. With existing laws, the following State organizations deal with the integrated flood management (Figure 1).

According to The Republic of Turkey laws:

- DSI is responsible to prevent the disaster effects of both surface and groundwater; and to build protective structures against the floods, and get benefits from its beneficiary uses,

- State Meteorological Institute (DMI) is responsible to supply the meteorological support to the sectors of agriculture, forestry, tourism, transportation, energy, health, and environment, military; on the other hand all kinds of climatic data are collected by DMI during floods,

- The law of General Directorate of Rural Affairs (KHGM) states has to prepare and apply some service and investment programs for the requirements of farmers in the rural areas in order to protect, develop and effective use of water and land resources in compliance with the politics and principals determined in the development plan and program. To reclaim the unsuitable land areas for agriculture, belong to the state or private; to prepare the needed reclamation projects for these areas to establish co-operations for the activities of soil conservation, land reclamation and irrigation.

Laws of Bank of Provinces (IB) and municipalities also states the responsibility of local organizations have to fight against the all natural disasters faced at the region under consideration, IB provides the funds and Municipalities spend it properly [8].

\subsection{Enforcement of the Laws}

The enforcement is realized by the close cooperation of the central government at capital city; and the government's top level representative at the provinces; where the flood disaster is encountered. The basic steps are the first aid, evacuation, safety, and shelter, normalization of the daily routines, rebuilding and recovery of local economy.

When a natural disaster like flood is encountered in a city, then the governor is top decision maker. The experts from various state organizations and mayor and army representatives help the governor to shape up the final decision. This expert group forms are called as "Crises Table (CT)". CT includes deputy governors, mayor, local army commander, the local representatives of DMI, DSI, State Highway Department (TCK), KHGM, civil defense, red crescent, fire brigade and other local nonovernmental organizations, like farmers union, trade union, chamber of commerce etc. In case of flood disasters, DSI and DMI local representatives play the most important role in decision-making [8].

\section{COOPERATION FOR FLOOD MANAGEMENT}

There should be a good and effective cooperation among the responsible institutes and local interest groups for flood management. A number of governmental and nongovernmental organizations have direct and indirect responsibility in integrated disaster management of floods in Turkey. AFET, General Directorate of Civil Defense, Army, Local Administrations and Municipalities. Institutional framework has three levels; namely, decision making, executive and users level. DSI is authorized to plan and manage all aspects and issues of flood management especially after the flood event.

In the long run, all the rehabilitation works are planned and realized by the state, but during the planning stage, all the local interest groups express their views freely. At this stage, local parliamentarians and administrations play the most effective role on deciding the priorities. When a flood disaster is encountered at a province, according to the existing laws, written rules and regulations defining the responsibilities of each organization in emergency case, legislation, administrative principles, hierarchy and the local traditions, Emergency Aid Organizations and Programs Related to Disaster Management initiated the following points:

- Pre-disaster planning,

- Set up some units of the different services in cities for disaster management,

- Set up other special service units and related details.

Generally, there are written rules and regulations defining the responsibilities of each organization in emergency case, but due to human factor, just after the disaster, there may be always chaos, but soon it is over and the system starts to work properly [8]. Of course there some local interest groups or organizations, which are Non-Governmental Organizations (NGOs) such as the 
unions of farmers, merchants, businessmen, and chamber of commerce. Elected representatives of the local people, mayor, helps to shape up the local public mind to deal with the similar type of floods in future. There may be economic help from the banks, rich local people, some nationwide campaigns to help the disaster hit area but usually these types of helps come afterwards and not sure. There are no written rules to define the type of the service the NGOs are expected to give, but their service is voluntary. So the state is the main healer and organizer of the helps.

\section{SOME FLOODS AND LANDSLIDES OCCURRED IN TURKEY}

Result of devastation of nature, we have been facing flooding, landslides which causes life and property loses over 80-years period of time. In 1910, it is recorded that after a large rainfall, Tokat-Behzat Stream overflows its blanks and flow over a barrack and cause 2000 people to die in one night. Our country face with 737-flood events during 1945-1990 and has lost 838 people. In 1957, Ankara-Hatip creek flooded and 185 people were died. In 1998 Macka-Catlak landslide is caused 65 deaths [10]. In Rize City, the maximum rainfall recorded as $4045.3 \mathrm{~mm} /$ year in 1931 , and in Igdir the minimum rainfall recorded as $114.5 \mathrm{~mm} /$ year in 1970 [11]. These given examples are the ones, which cause the most death in near history. This does not mean that flooding and landsliding do not cause life loss nowadays. Recently, after a heavy rainfall, number of life or properties loses can occur in many region of our country. However, it is good to say that lost of lives minimized with the gained experiences from past events. On the other hand, it is not possible to say same thing for properties loss.

\subsection{Study Area: Zonguldak-Bartin Basin}

Zonguldak-Bartin region is located on north of Turkey. In 1998, there was a major flooding in the region (Figure 2). Due to this devastated flooding, people lost their life and numbers of engineering structures built on the river and surrounding area were totally destroyed or heavily damaged. The damages caused by flooding may be classified in four categories as follows:

- Heavy damages in both side of river bed and its surrounding areas such as interstate and intercity highways (Figure 3).

- Destructive damages on bridge which connect both side of river (Figure 4).

- Totally and slight damaged buildings (Figure 5).

- Localized landsliding phenomena (Figure 6).

Both side of the canal were covered with muddy soil having 0.10-0.15 $\mathrm{m}$ thickness (Figure 1). This thickness reaches more than $0.50 \mathrm{~m}$ in some locations specifically near the riverbed (Figure 3). River water rose approximately $3.00 \mathrm{~m}$ during flooding. Then, cleaning up process took sometimes in the region.

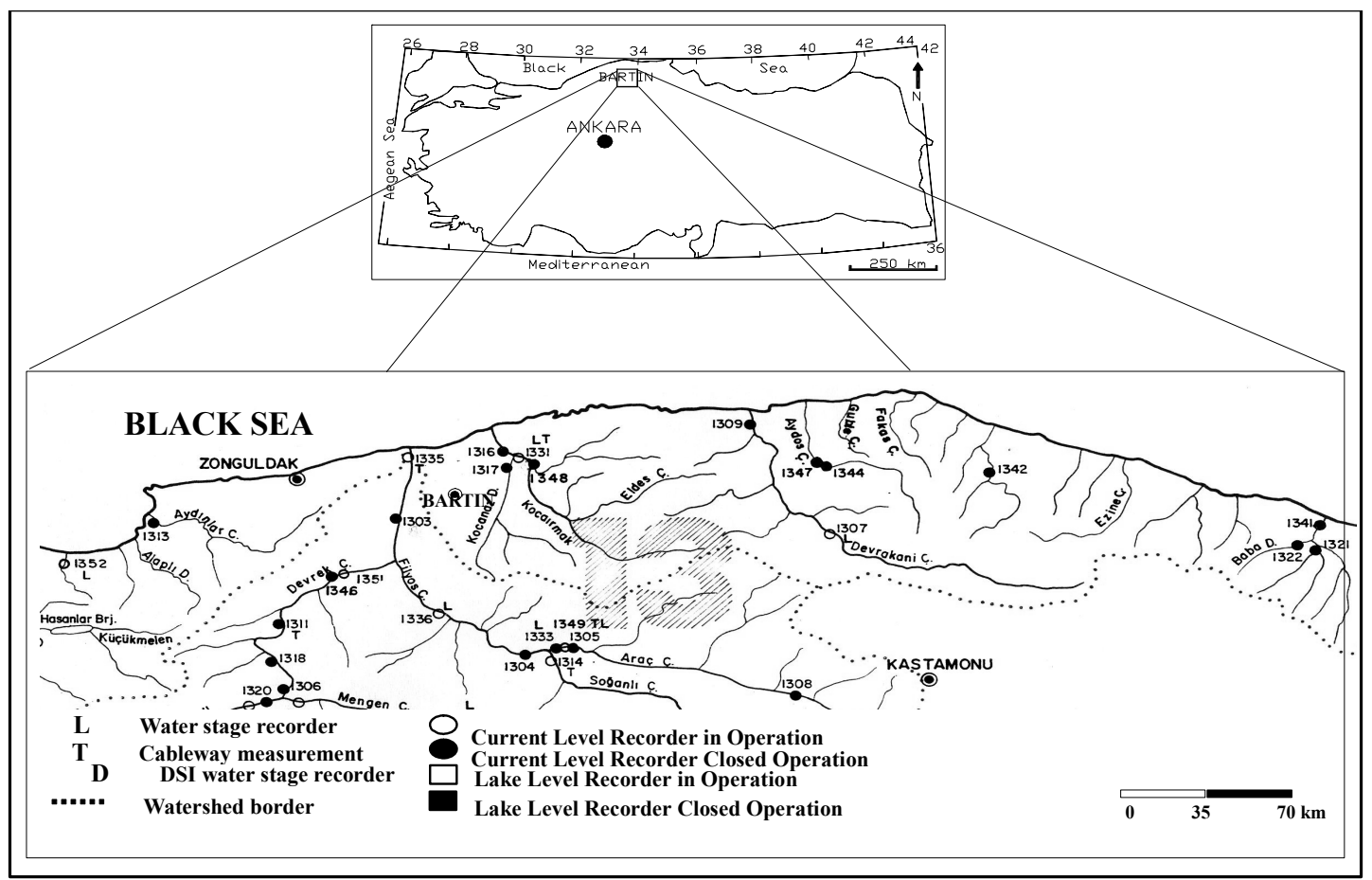

Figure 2. The case study area. 


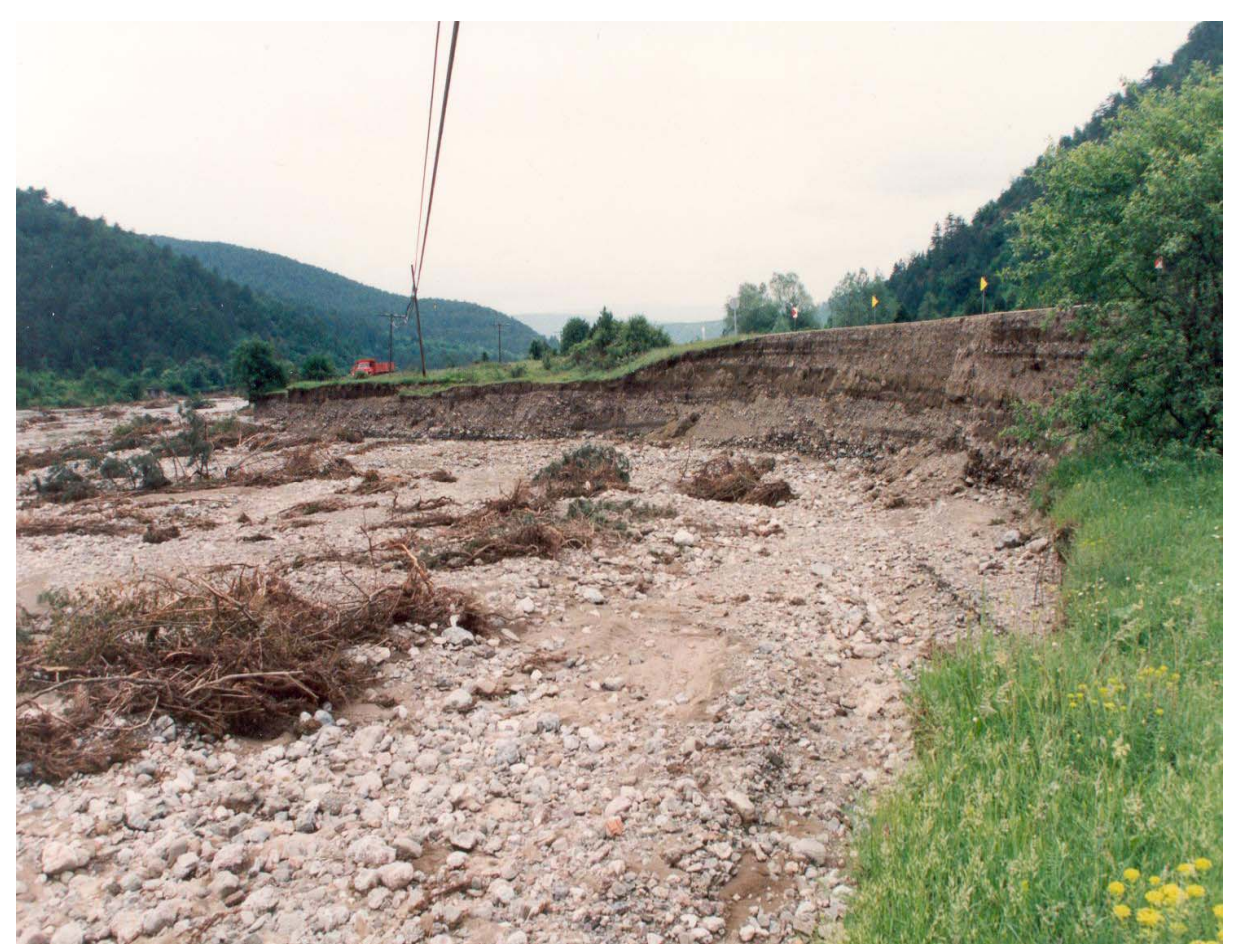

Figure 3. Intensive damages occurred in riverbed [1].

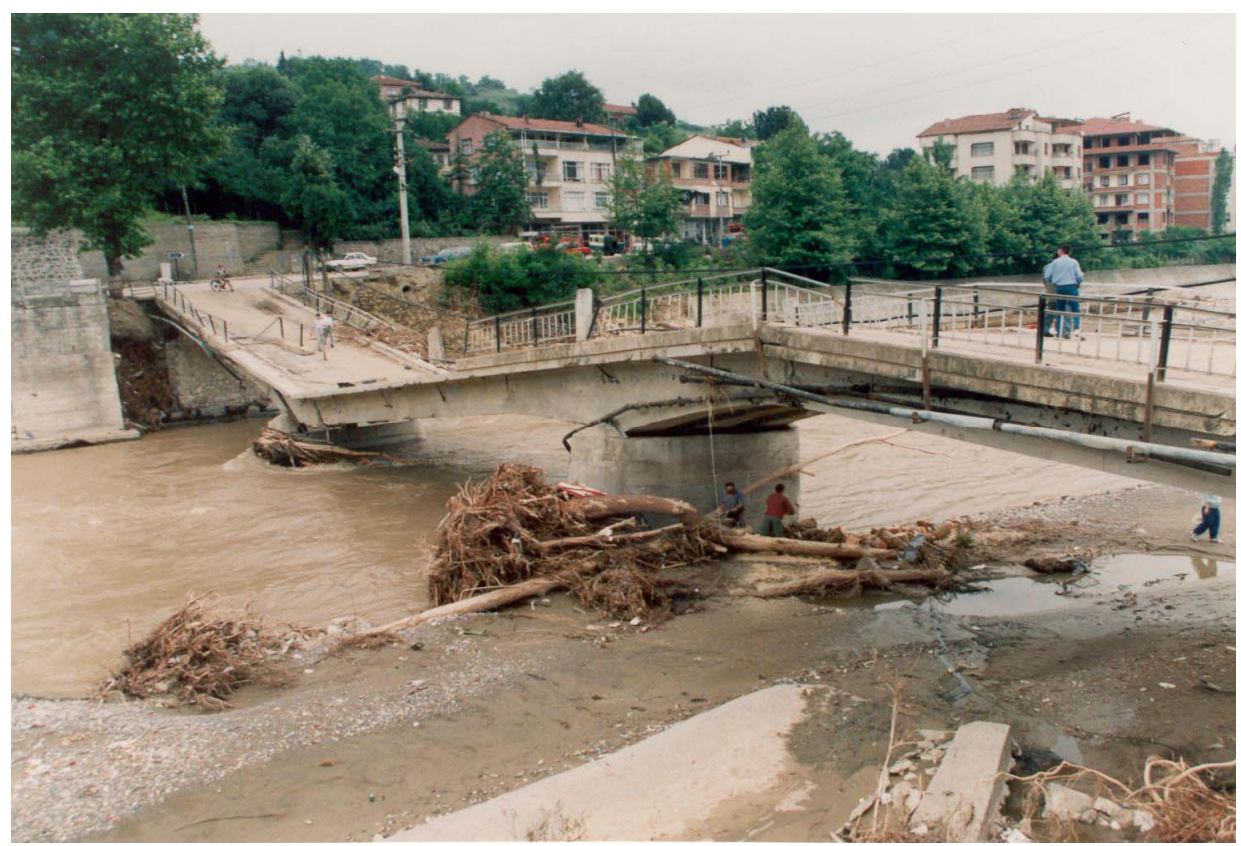

Figure 4. One of the totally damaged bridges [1].

\section{RELATION BETWEEN EROSION, FLOODING AND HEAVY PRECIPITATION}

In world, 25-billion tons of earth loses through erosion in every year. In the other word, 0.5-2.0 tons of onehectare earth loses in each year. In last fifteen years, agricultural terrain/person rate decreases $14.3 \%$ in devel- oped countries and $40 \%$ in developing countries. If this decreasing tendency goes on this rate will decrease by $50 \%$ in 2050 [10]. Erosion is one of the most important problems of the world. According to United Nations Environment Program (UNAP), $25 \%$ of the world terrain and 900 million people effect from erosion. World soil loss through erosion is 480 billion ton in last 20 years. 


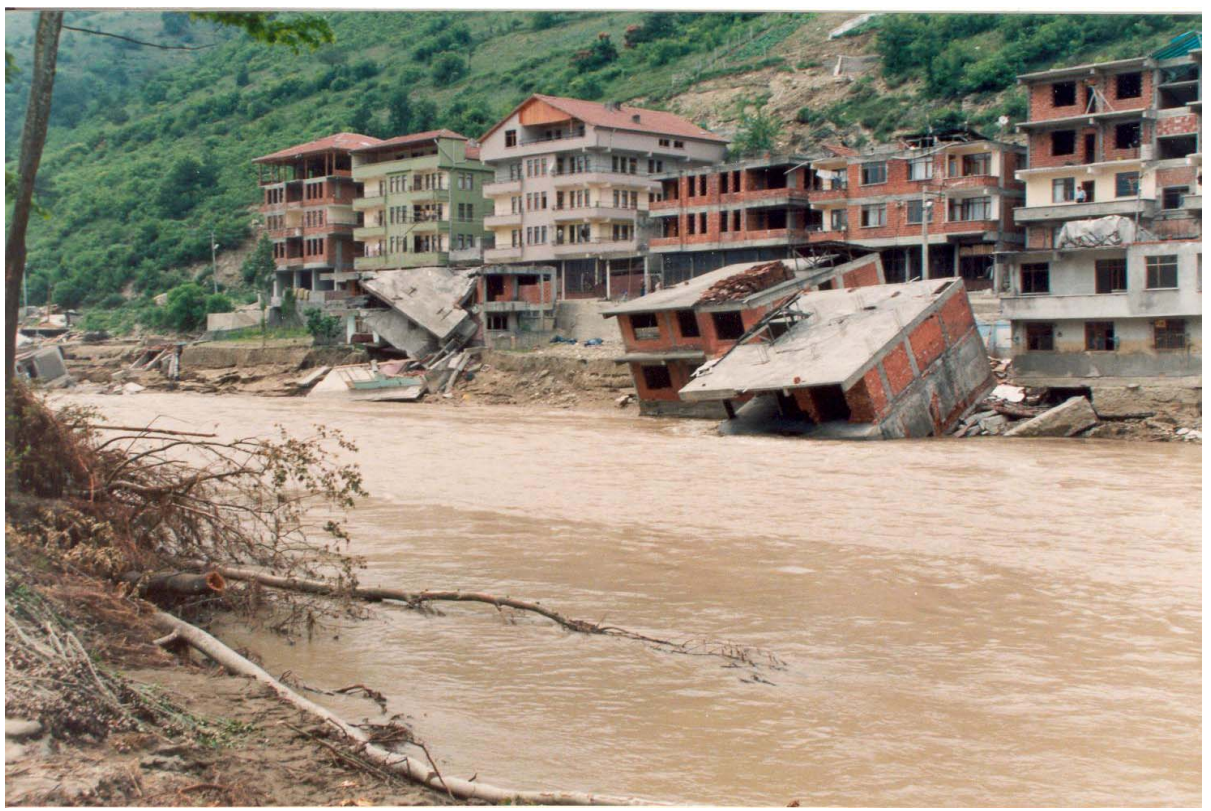

Figure 5. Totally destroyed buildings along the riverside [1].

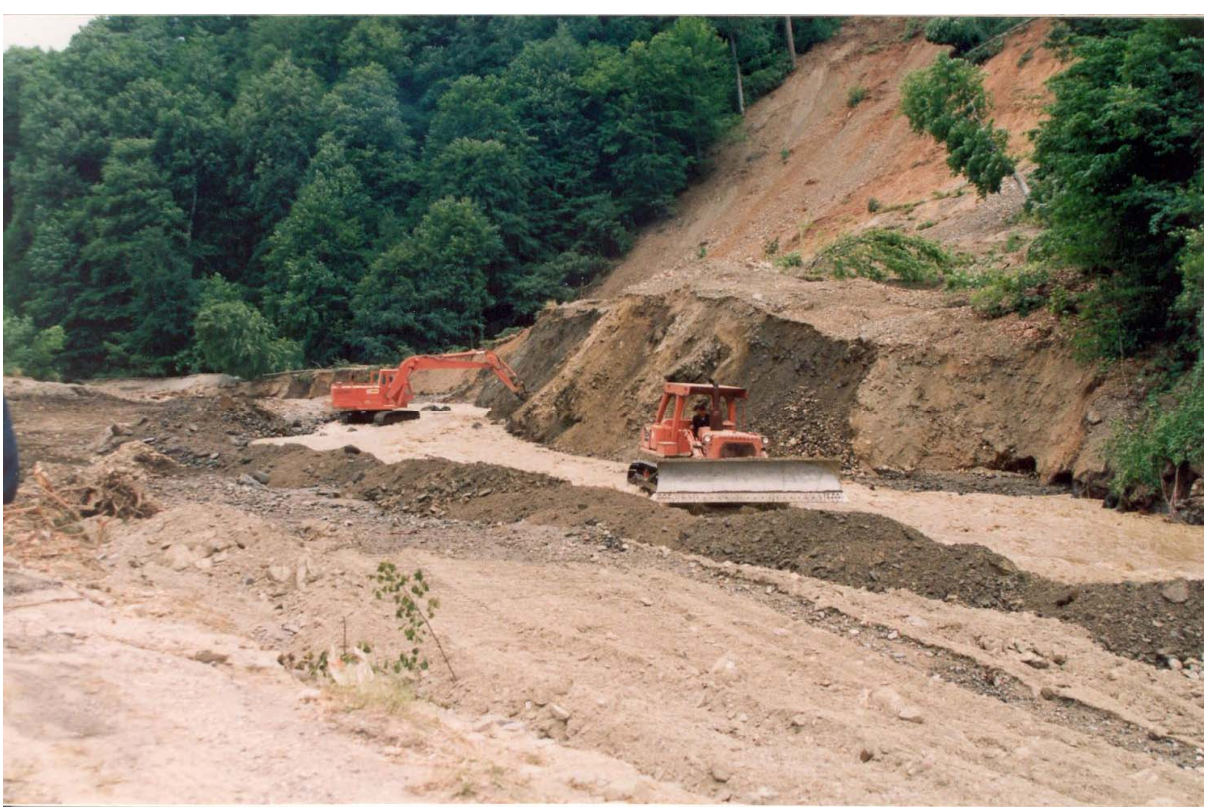

Figure 6. Landslides occurred at some location along the riverbed [1].

Turkey is under erosion condition that all type and intensity of erosion can be seen. Therefore, our country loses 500 million tons of soil, which is enough to fill 150000 trucks, and can cover Sakarya City with a $29 \mathrm{~cm}$ thick stratum [12]. $86 \%$ of our country soils face with erosion danger [13]. In our country, the dragging material amount in riverbeds is 600 million ton. This is 1.8 times the all Europe's related value, 320 million ton [14]. Erosion or soil weathering is a break down in nature balance occurs with loss of forests and pastures in slopes. After erosion, in erosion zone, it can be seen that water balance changes and (after a rain, by the incoming water from slopes and creeks) there can be floods if the geological structure and other factors are appropriate.

By weathering, soil loses its upper (organic) strata, which is rich in organic materials and fragmental, big pores occur by the effect of this organic material. This upper stratum absorbs much of the rainwater as a sponge so flowing rainwater decreases, by lose of this upper strata approximately all rainwater flows along the surface and in this condition floodplains occur [11]. Because of being in a crossing zone as a geographical loca- 
tion, the half zone climate conditions are dominant. Therefore, majority of precipitations are in short or long time which causes erosion. Although the mean rainfall is $643 \mathrm{~mm}$ for Turkey, it is possible to see (according to time and location) rainfall values like $220 \mathrm{~mm}$ or $2500 \mathrm{~mm}$ as in eastern Black Sea region of Turkey. In inner and eastern region, rainfall mean is less than $400 \mathrm{~mm}$. Between October-January, period that is important for agriculture; rainfall mean was $313.9 \mathrm{~mm}$ earlier, this mean decreased to $249.4 \mathrm{~mm}$ by $23.8 \%$ lose in October 1999-January 2000 period and to $190.1 \mathrm{~mm}$ by $39.5 \%$ lose in October 2000-January 2001 period [10].

Turkey is not a rich country in water resources. If this decreasing tendency goes on, today's water amount, which is $2860 \mathrm{~m}^{3} /$ person/year, will decrease to $1240 \mathrm{~m}^{3} /$ person/year in 2050 and $700 \mathrm{~m}^{3} /$ person/year in $2100.2 / 3$ of rainfall dropped on the earth surface starts flooding [10].

\section{RECENT CHANGES IN THE FLOOD MANAGEMENT}

The floods of the last decade, with their costly results have brought Turkey to a new view-point to reduce and control the susceptibility to the flood damages, namely the "Integrated Flood Management". In this context, a sound underwriting for land use control, flood insurance and early warning system are being considered. It can be said that from the years of experiences gained showed structural measures such as dams, levees and dykes, diversions, channel improvements, implemented in the basin-wide were effective with rather high cost, to reduce the risk in flood damage. Therefore non-structural measures are becoming more important in flood hazard management in the country.

\section{CONCLUSIONS AND SUGGESTIONS}

Devastation of forests and because of this loses of pastures and plants are fundamental reason for erosion. Then, extensive damages will occur due to flooding and land sliding. The biggest damage caused by erosion is losing the fruitful earth, which formed by thousand year periods. In order to evaluate the important of this, it assists that thinking a tree can produce a benefit, which is 2000 times its wood profit. Erosion is an important reason for agricultural production. Due to erosion and unsuitable use of agricultural terrains, decreasing agricultural terrains become insufficient to rapidly growing population so migration from villages to cities accelerates. The dams and other flood control structures played very important role in protecting the human life. However, flood control and management based on structural solutions could be insufficient. Therefore, effective solutions based on land use control, zoning, building ordi- nance, modifications in building codes, flood information programs by local communities are needed. This required major restructuring of both present legal systems and institutions responsible for management.

The flood plain use along the narrow valleys, encouraged by local civil administrations, had to be put under control. Otherwise, future human loss will be greater. During a flood, prior to all the state organizations should cooperate. In this respect, DSI, General Directorate of Electric Power Resources Survey and Administration (EIE) and DMI should be able to work together. From the view point of flood, considering the old experiences, to decrease of the flood damages or to take under control the flood some suggestions proposed for countries especially developing countries would be as follows:

- They should improve early warning system,

- They should prepare hazard mitigation plans and strategies and,

- They should be supplied with scientific and technical information about the flood.

\section{REFERENCES}

[1] Arman, H. (2004) Overview of flooding damages and its destructive consequences in Turkey: A case study of Zonguldak-Bartin flooding in 1998, Turkey. NATO Advanced Research Workshop, Ostrov u Tise.

[2] Yuksel, I. (2003) River erosion in eastern Black Sea region and scientific approaches aimed to prevent those events. Journal of Engineering Bulletin, Chamber of Civil Engineering, Trabzon Division, 17(62), 8-9.

[3] Yuksel, I., Onsoy, H. and Yuksek, O. (2005) Analyzing of river and coastal erosions based on the characteristics properties of the eastern Black Sea. 5th Nationally Coastal Engineering Symposium, Bodrum, 5-7 May 2005, 75-87.

[4] Yuksel, I. and Yuksek, O. (2003) Analysis of erosion in eastern Black Sea region with the latest developments. Journal of Natural and Human, 37(2), 2-8.

[5] Yuksel, I. and Yuksek, O. (2004) Studying to prevent of the flood in the settling and agricultural areas in the eastern Black Sea region. Journal of Natural and Human, 38(3-4), 64-67.

[6] Foody, M.G., Ghoneim, M.E. and Arnell, W.N. (2004) Predicting locations sensitive to flash flooding in an arid environment. Journal of Hydrology, 292(1), 48-58.

[7] Seker, D.Z., Goksel, C., Kabdasl1, S., Musaoglu, N. and Kaya, S. (2003) Investigation of coastal morphological changes due to river basin characteristics by means of remote sensing and GIS techniques. Journal of Water Science Technology, 48(10), 135-142.

[8] Gurer, I. and Ozguler, H. (2004) Integrated flood management case study1 Turkey: Recent flood disasters in northwestern Black Sea region. World Meteorological Organization, the Associated Programme on Flood Management.

[9] Keller, E.A. (2000) Environmental geology. 8th Edition, Prentice-Hall, Inc., New Jersey. 
[10] Gunay, T. (1997) Forest, Unforestation Soil Erosion. The Turkish Foundation for Computing Soil Erosion for Reforestation and the Protection of Natural Habitats (TEMA), Istanbul.

[11] http://www.meteor.gov.tr (accessible 2008).
[12] http://www.tema.org.tr (accessible 2008).

[13] http://www.agm.gov.tr (accessible 2008).

[14] Burak, S., Duranyildiz, I. and Yetis, U. (1997) National environmental action plan: Management of water resources. State Planning Organization (DPT), Ankara. 